DOI https://doi.org/10.18551/rjoas.2018-09.27

\title{
RELIGIOSITY INFLUENCES TOWARDS TAX COMPLIANCES IN SIDOARJO
}

\author{
Anggada Satria Duta Arya \\ Department of Accounting, Faculty of Economics and Business, University of Airlangga, \\ Indonesia \\ E-mail: satriadta@gmail.com
}

\begin{abstract}
Tax and religion are two sensitive topics that are rarely discussed in general. This is because these two topic considered as private by many people. However, reliogisity is a noneconomic factor that often neglected on previous researches. The role of religiosity towards tax compliance has been studied many times. The roles found to be significantly affecting tax evasion in some countries. Unfortunately, many researchers also found that religiosity does not affect tax compliance; it functions merely as fundamental of life for some people. On this paper, we want to find the role of religiosity towards tax compliance in Sidoarjo. Sidoarjo is one of the busiest city in East Java, Indonesia. The result of this study indicates that religiosity does not play significant roles towards tax evasion in Sidoarjo. The taxpayers tend to use morale and social reasons as the base for them to comply with tax regulations.
\end{abstract}

\section{KEY WORDS}

Tax, tax compliance, religiosity, tax morale.

Tax revenue is one of the important sources of income for the nation. It serves as one of the component that makes budgeting and public expenditure. Tax revenue can also be used to measure the strength of government policy towards its citizen. Hence, many tax authorities in every country try to improve tax revenue in every section. One of the improvements that they are trying to improve is the compliance section. Tax compliance is not a new subject. In fact, it has been reviewed and researched many times. Most of the research was based on the economy factors on why people not paying tax, where in fact, the numbers of non-payers are lower than the number of those who complied. Therefore, economy factors should not be used as the only variables to determine tax compliance. There were many evidence that non-economic factors such as culture, government rules and morale affected people behavior towards tax compliance.

One of the non-economic factors that are being researched is related to tax morale. Tax morale defined as intrinsic intentions of taxpayers to pay taxes (Torgler, 2005). One of the factors that shaped of individual's morality is religiosity (Pope \& Mohdali, 2010). Reliogisity is a non-economic factor that often neglected on previous researches because it has negative relationship with the economic development in a country (Stark \& Bainbridge, 1996).

Simply put, the term religiosity is defined as a condition in which humans believe in the great power that controls their lives so they have an obligation to obey, believe, and also worship this power. The concept of religiosity cannot be related to the concept of 1 (one) religion, but the meaning is broad and too complex. People who have religion and believe in God(s) can be said to have high moral values. But atheists or those who have no religion, may have higher morals. So, in the context of this tax compliance, researchers will only take the religiosity factors that are common in the understanding of the Indonesian.

Tax compliance can be defined as a taxpayers' intention to report all income and deduction of their income as truest as possible in a timely manner and in accordance with applicable rules (Roth, Scholz, \& Witte, 1989). Whereas in the neo-classical paradigm defines taxpayers as individuals who have a very good moral understanding, risk aversion, are able to choose alternatives to maximize income so it is obligatory to commit noncompliance in the form of tax evasion when it is felt that taxes are a burden that reduces their income (Milliron \& Toy, 1988). Thus, according to the neo-classical paradigm, the way to 
prevent the occurrence of tax evasion is to provide greater sanctions and fines and also tighten tax rules and frequent tax audits.

As we aware, Indonesia is one of the most populous countries with Moslem as one of the majority religion in the country. Unfortunately, the number of tax-related fraudulents and avoidance are very high. This resulted in lower public trust towards government official. Hence, our research is trying to find the significance of religiosity towards tax compliance in Indonesia.

This paper is organised as follows, part one is brief introduction to the research issue. Following that, chapter 2 will focus on the theoretical basis of religiosity and tax compliance according to the definition and results of previous studies. Chapter 3 will focus on the type of research, measurement and data processing. Chapter 4 will explain the results of the research obtained by the method in the previous chapter. Chapter 5 focuses on the conclusions of the research and the limitations of the study.

\section{LITERATURE REVIEW}

Tax and religion are two sensitive topics that are rarely discussed in general. This is because these two topics considered as private by many people. Discussing taxes will not escape the assumption that the questioner wants to know how much the individual's income is, whether the individual understands tax regulations and the most important thing is whether the individual has carried out his tax obligations properly. The same thing applies if we ask individuals about religion. Religion is private and has different sensitivity for each individual. A view of the same religion may have different meanings for each individual. This causes research related to religion to be difficult because of the limitations and reluctance of the resource person to answer the questions posed by the researcher.

Religion can be defined as a supernatural and spiritual system that governs the behavior, views and ethics associated with a text, holy place or religious affiliation (Morreall \& Sonn, 2012). Meanwhile, religiosity is the level of obedience that is owned and held by each individual of the religion he holds. Johnson, Jang, Larson \& De Li (2001) defines religious commitment or religiosity as "the extent to which an individual is committed to the religion he embraces and his teachings, so that individual attitudes and behavior reflect this commitment". In other words, it can be concluded that one's religion can be seen by others, but the level of religiosity can only be known by that person. As commensurate with habit, religiosity can be used as a control and regulator of how individuals act, thus making our social life more predictable and making individuals feel calmer and safer when facing uncertainty (Heiner, 1983).

Glock (1962) divided religiosity into 5 (five) dimensions. The first four dimensions are religious beliefs, practices, experiences and knowledge which then form the final dimension of behavior. However, it is still difficult to measure the religiosity of each individual because this religiosity has many variables, such as religion itself, culture, socioeconomic factors, etc. Peter (1999) wrote a book about how to measure religiosity with a focus on the perspective of western religion. In this book, he divides measurements into categories such as beliefs and practices, religious attitudes, religious orientation, religious development, religious commitment and involvement, religious experience, and moral values. There are many variations and variables to measure religiosity, so many researchers only use a few points such as church attendance, church participation, religious education, religious beliefs, importance of religion, religious guidance and trust in church - to represent religious obedience (Torgler, 2006).

Religiosity seems to be a complex concept that includes not only observable behaviors and attitudes but also unobservable beliefs, feelings, and experiences. So referring to previous research, religiosity can be seen from two main perspectives: religious affiliation and religious commitment.

Religious affiliation refers to certain religious groups held by individuals such as Islam, Christianity, Buddhism and Hinduism. Lenski (1961), "religion is the bearer of complex subcultures that are relevant to almost all phases of human existence and group social 
heritage products". Thus the historical values of different religious affiliations can affect individual behavior differently. Religious commitment is divided into two types, namely intrapersonal religiosity that comes from individual beliefs and attitudes and interpersonal religiosity that develops from individual involvement with religious communities or organizations (Pope \& Mohdali, 2010).

Indonesia is a country that upholds religiosity as well as a multicultural country based on the principle of divinity. This principle is clearly illustrated from the first principle of Pancasila, as the basis of the moral and norms and ethics of the Indonesian people. This principle of divinity is realized in the form of religious recognition. Religion is one of the fundamental points in human life. In religion itself, not only regulates the relationship between humans and the Creator but also. The general concept of this practice is of course to create a peaceful, fair, prosperous and tolerant relationship between human beings. With religion, each individual may have control over the behavior used as a spiritual human being (Anderson \& Tollison, 1992).

Tax compliance is not a hotcake issue for the economy throughout the world. This problem arises in both developed and developing countries. In general, the conflict between taxpayers and tax authorities is mostly the same in every country. Taxpayers and tax authorities always have differences of opinion regarding tax compliance. For taxpayers, they generally assess taxes as an expense that reduces their income without giving concrete contributions in the short term. On the other hand, tax authorities see tax as a source of income and contributions that can help the country's economic growth. Unfortunately, many tax frauds make taxpayers think otherwise and find it futile to obey the rules if the ends are used for certain groups.

Taxpayers tend to carry out their tax obligations only to a safe point where they are not fined from delaying their obligations. This situation will bring apathy from the taxpayer, because they do not care for what their money is used and the arbitrariness of certain parties who feel free to misuse tax money. To minimize the boomerang effect of this government power, the tax authorities must foster public trust in their performance. Some of the ways commonly used to improve tax compliance and also show the power of legislation are promoting tax audits for business entities or taxpayers who have above-average income values, giving higher penalty rate and severe penalties that could be an example for those non-payers.

This trust could grow along with the realization of government promises such as increasing public facilities, easy access to taxation services to a reduction in tax rates if possible. According to researchers, the tax authorities and the Indonesian government in general have succeeded in showing positive improvements in the management of tax funds. This is realized by increasing comfort in some public facilities. Concrete evidence of increased taxpayer trust is indicated by the increase in receipt and reporting of the 2017 SPT OP amounting to $10,589,648$ or an increase of $14 \%$ compared to the 2016 OPT SPT revenue (Novalius, 2018). Alm and Torgler (2006) stated that the trust factor in the government system can help increase tax compliance since voluntary in a country.

Pope and Mohdali (2010), conducted a study of the effect of religiosity on tax morals and tax compliance. This research was conducted using data from the World Value Survey (WVS) involving 99 countries with different cultural, economic and religious backgrounds. Although it has a wide range of resources and topics, the use of data from WVS has its own constraints. It is difficult to determine the level of religiosity from the speakers because of differences in cultural background and also the teachings adopted. There are variations between different religions, even in same religion, different beliefs and practices are adopted. These differences are influenced by different cultures formed from the historical values of each individual in various countries. In addition, the probability of misunderstanding survey questions is also greater because these questions are universal.

Torgler (2006) used data from the World Value Survey as Pope did, but with different years ranging from 1995-1997. The use of data from WVS is considered to represent $70 \%$ of the world's population, so the reliability of the data from this survey can be justified. Torgler uses a sample of 40 countries in this study. The findings in the study support previous 
studies by combining non-economic factors into tax compliance analysis. From the data obtained in almost all the major religions in 40 countries, it found that people's morale was influenced by the magnitude of the role of religion, such as religious perception and understanding, activity in places of worship and the principles of religious life.

In 2016, a research was conducted in Turkey with a sample of 408 individual taxpayers in Malatya, Turkey. According to his research, the entrepreneurs have higher flexibility because they can report their income according to their wishes, in contrast to private employees who report their taxes through their place of work. Benk also found data that interpersonal religiosity has a greater role in influencing human behavior and outlook compared to intrapersonal religiosity especially in Turkey (Benk, Budak, Yüzbaşı, \& Mohdali, 2016).

As a respond for aforementioned research, another cross-country comparison research conducted between Malaysia and Turkey. In this study, Mohdali did not take new data from the country of Turkey, but used the same data as the data obtained by Benk. As a comparison of the data, Mohdali conducted data sampling in Malaysia which involved as many as 200 sources from 17 companies in Klang Valley and Putrajaya, all sources of Islam and Malay ethnicity. The results of this study found that voluntary tax compliance in both countries have higher mean which means that taxpayers from these two countries have high tendency to comply with tax laws without voluntary compliance. Research by Benk (2016) and Mohdali (2017) concludes that Muslims in Turkey and Malaysia have high levels of compliance, especially voluntary compliance due to strong interpersonal religiosity (Mohdali, Benk, Budak, Mohdlsa, \& Yussof, 2017).

Another research was carried out by Eiya (2016). Eiya conducted a study in Nigeria involving 342 Muslim and Christian speakers. In this study found no significant differences in Christian and Muslim tax compliance behavior in Nigeria. This study concludes that religious values alone do not play an important role in making taxpayers responsible for tax compliance. However, Nigerian WPs are not affected by the threat of penalties imposed by the tax authorities but are more influential on social factors that encourage their willingness to voluntarily comply with tax laws (Eiya, Ilaboya, \& Okoye, 2016).

In Indonesia, the influence of religiosity on tax compliance was studied in 2016. Utama (2016), conducted a study of the effect of religiosity on personal taxpayer compliance behavior involving 296 resource persons from WP OP in DKI Jakarta province. This study found that the components of interpersonal religiosity have a significant effect on voluntary tax compliance, while for the component of Intrapersonal Religiosity does not significantly influence voluntary tax compliance.

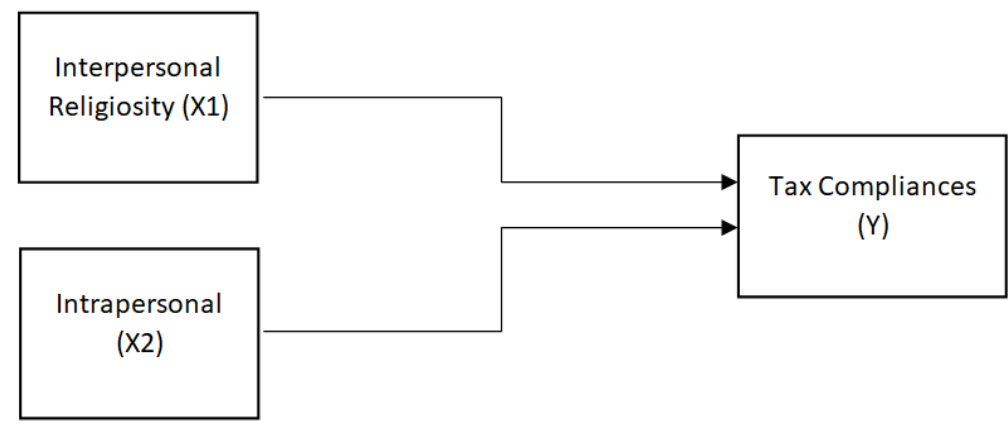

Figure 1 - Conceptual Framework

Using several findings from previous studies, the author draws inspiration from Pope's research (2010) which was later specifically re-verified by Benk (2016) and Mohdali (2017) about the effect of religiosity on tax compliance. From these previous studies, the authors conclude that religiosity has a significant role in tax compliance. To find out the significant role of interpersonal and intrapersonal religiosity in Indonesia, the authors use the conceptual framework as follows to facilitate the research process so that it remains in the planned scope and objectives. 
H1: Interpersonal Religiosity influences tax compliance significantly;

$\mathrm{H} 2$ : Intrapersonal Religiosity influences tax compliance significantly.

\section{METHODS OF RESEARCH}

This research is a quantitative research that uses the process of data in the form of numbers as a tool to analyze and conduct research studies (Kasiram, 2008). Data from this study are primary data using questionnaires distributed to resource persons both directly and online. In this study the author uses two variables, the dependent variable and the independent variable. Independent variables include two variables, intrapersonal interpersonal and religious religion. There are 5 questions in each of these variables. These variables are then measured by a 5-point Likert scale, namely 1 stating strongly disagree and 5 strongly agree. Next one is the dependent variables. The dependent variable is the variable that is directly affected by the independent variable. The results of this variable determine how the hypothesis of a study can be answered. In this study, the dependent variable is tax compliance. There are 5 questions in this variable which are rated with a 5-point Likert scale.

Data collection will be focused on Sidoarjo, East Java. The target data to be collected for this study is a about 300 correspondents. This study uses primary data as research material. This primary data is data collected or obtained directly by researchers. The main instrument in this study is a questionnaire that will be given to correspondent. This questionnaire will be made in the form of an online questionnaire and in manual form. For online questionnaires, links will be distributed through social media, email and whatsapp. For manual questionnaires, researchers will disseminate to several points in offices and public areas in Sidoarjo. The sampling method will be carried out using covenience sampling. Convenience sampling is most commonly used during the research phase due to the collection of information from members of the population who are voluntarily giving their answers and opinions so that the basic information obtained is faster and more efficient (Sekaran, 2016).

\section{RESULTS OF STUDY}

Table 1 - Demographic Details

\begin{tabular}{|c|c|c|c|}
\hline \multicolumn{2}{|c|}{ Demographic Characteristics } & $\mathbf{n}$ & $\%$ \\
\hline \multirow{2}{*}{ Sex } & Male & 206 & 60.4 \\
\hline & Female & 135 & 39.6 \\
\hline \multirow{5}{*}{ Age } & $18-24$ & 38 & 11.1 \\
\hline & $25-34$ & 149 & 43.7 \\
\hline & $35-44$ & 101 & 29.6 \\
\hline & $45-54$ & 44 & 12.9 \\
\hline & $55-65$ & 9 & 2.6 \\
\hline \multirow{4}{*}{$\begin{array}{c}\text { Employment } \\
\text { Status }\end{array}$} & Self-Employed & 63 & 18.5 \\
\hline & Civil Servant & 58 & 17 \\
\hline & Private Employees & 207 & 60.7 \\
\hline & Other & 13 & 3.8 \\
\hline
\end{tabular}

The table shows majority of responded are male which cover $60 \%$ of total respondents of 341 peope. In addition to that, most of the respondents are in productinve age between 25-34 years old.

The correlation test on interpersonal religiosity shows that majority of respondents believes that God is always with them and religion is the foundation of their life. Unfortunately, it didn't reflect well on their intrapersonal religiosity in which they don't really like to spend their money on donation, although most of the respondents are keen to socialize with their fellows colleagues in religious events. Our assumption from the lack of donation willingness is because they want to keep the charitable activity private as if they 
show their action to others it may be rejected by God. At least, that is the perspective in Islam, which is the major religion in Sidoarjo.

Table 2 - Correlation

\begin{tabular}{|l|l|r|}
\hline \multicolumn{2}{|c|}{ Correlations } \\
\hline \multirow{4}{*}{ Interpersonal Religiosity } & Pearson Correlation & Tax Compliance \\
\cline { 2 - 3 } & Sig. (2-tailed) & -0.032 \\
\cline { 2 - 3 } & $\mathrm{N}$ & 0.559 \\
\hline \multirow{3}{*}{ Intrapersonal Religiosity } & Pearson Correlation & 341 \\
\cline { 2 - 3 } & Sig. (2-tailed) & $.170^{* *}$ \\
\cline { 2 - 3 } & $\mathrm{N}$ & 0.002 \\
\hline \multirow{2}{*}{$* *$ Correlation is significant at the 0.01 level (2-tailed). } \\
\hline
\end{tabular}

Correlation analysis between dependent and independent variables shows no significance relationship between religiosity and tax compliance. This result is in line with the research from Cahyonowati (2011). Other than religion, individual intrinsic motivation in the form of tax morality is a positive determinant of tax compliance behavior. The responsibility as a citizen as well as positive improvements towards public facilities is playing important roles in determining tax compliance Sidoarjo. People tend to differentiate between the duty of citizen and the duty to God. Hence, religiousity doesn't really affect tax compliance in Sidoarjo but more as a fundamental basis in to do better in life.

The result are also supported by the research of Feld \& Frey (2007). Tax compliance arises from interactions between government and taxpayers. This interaction is built on the basis of trust and requires a short amount of time, so that it implements a psychological contract between the taxpayer and the government. Tax authorities treat taxpayers well so that the taxpayer's voluntary nature to pay taxes (Feld \& Frey, 2007).

\section{CONCLUSION}

This research concludes that there is no significance relationship between religiosity and tax compliance. People tend to use religion as the foundation of their life, but it is not the solely factor. The intrapersonal religiosity shows higger correlation value compare to interpersonal religiosity. It proves that individual in Sidoarjo are more concern about the social and cultural value. People are complying with the tax authorities and rules due to their beliefs as a citizen and positive treatment from the government.

Future research could look more into the specific demographic factors and religion. From there, they may find significancy between religion and tax compliance. Also, it is not impossible to add more cultural and social variables such as the satisfaction towards government or whether political situation affects tax compliance.

\section{REFERENCES}

1. Alm, J., \& Torgler, B. (2006). Culture differences and tax morale in the United States and in Europe. Journal of Economic Psychology, 27(2), 224-246.

2. Anderson, G. M., \& Tollison, R. D. (1992). Morality and monopoly: the constitutional political economy of religious rules. Cato J., 12, 373.

3. Benk, S., Budak, T., Yüzbaşı, B., \& Mohdali, R. (2016). The impact of religiosity on tax compliance among Turkish self-employed taxpayers. Religions, 7(4), 37.

4. Cahyonowati, N. (2011). Model Moral Dan Kepatuhan Perpajakan: Wajib Pajak Orang Pribadi. Jurnal Akuntansi dan Auditing Indonesia, 15(2).

5. Eiya, O., llaboya, O., \& Okoye, A. (2016). Religiosity and tax compliance: Empirical evidence from Nigeria. Igbinedion University Journal of Accounting, 1, 27-41. 
6. Feld, L. P., \& Frey, B. S. (2007). Tax compliance as the result of a psychological tax contract: The role of incentives and responsive regulation. Law \& Policy, 29(1), 102-120.

7. Glock, C. Y. (1962). On the study of religious commitment.

8. Heiner, R. A. (1983). The origin of predictable behavior. The American economic review, 73(4), 560-595.

9. Hill, P. C., \& Hood, R. W. (1999). Measures of religiosity: Religious Education Press Birmingham, AL.

10. Johnson, B. R., Jang, S. J., Larson, D. B., \& De Li, S. (2001). Does adolescent religious commitment matter? A reexamination of the effects of religiosity on delinquency. Journal of Research in Crime and Delinquency, 38(1), 22-44.

11. Kasiram, M. (2008). Metode Penelitian Kuantitatif-Kualitatif. UIN-Malang Press, Malang.

12. Lenski, G. E. (1961). The religious factor: A sociological study of religion's impact on politics, economics, and family life.

13. Milliron, V., \& Toy, D. (1988). Tax compliance: an investigation of key features. The Journal of the American Taxation Association, 9(1), 84-104.

14. Mohdali, R., Benk, S., Budak, T., Mohdlsa, K., \& Yussof, S. H. (2017). A cross-cultural study of religiosity and tax compliance attitudes in Malaysia and Turkey. eJournal of Tax Research, 15(3), 490-505.

15. Morreall, J., \& Sonn, T. (2012). The Religion Toolkit. A Complete Guide to Religious.

16. Novalius, F. (2018). Pelaporan SPT 2017 Akhirnya Rampung, Simak Faktanya. Retrieved from https://economy.okezone.com/read/2018/04/01/320/1880601/pelaporanspt-2017-akhirnya-rampung-simak-faktanya

17. Pope, J., \& Mohdali, R. (2010). The role of religiosity in tax morale and tax compliance. Austl. Tax F., 25, 565.

18. Roth, J. A., Scholz, J. T., \& Witte, A. D. (1989). Taxpayer Compliance, vol. 1 and vol. 2: Philadelphia: University of Pennsylvania Press.

19. Sekaran, U., \& Bougie, R. (2016). Research methods for business: A skill building approach: John Wiley \& Sons.

20. Stark, R., \& Bainbridge, W. S. (1996). A theory of religion: Rutgers Univ Pr.

21. Torgler, B. (2005). Tax morale and direct democracy. European Journal of Political Economy, 21(2), 525-531.

22. Torgler, B. (2006). The importance of faith: Tax morale and religiosity. Journal of Economic Behavior \& Organization, 61(1), 81-109.

23. Utama, A., \& Wahyudi, D. (2016). Pengaruh Religiusitas terhadap Perilaku Kepatuhan Wajib Pajak Orang Pribadi di Provinsi DKI Jakarta. Jurnar Lingkar Widyaiswara, 3(2), 113. 